\title{
Improved or Unimproved Urban Areas Effect on Soil and Water Quality
}

\author{
Sally D. Logsdon ${ }^{1, *}$ and Patricia Sauer ${ }^{2}$ \\ USDA-ARS-NLAE, Ames, IA 50011, USA \\ 2 Iowa Stormwater Education Partnership, Ames, IA 50010, USA; psauer@iowastormwater.org \\ * Correspondence: sally.logsdon@ars.usda.gov; Tel.: +515-294-8265 \\ Academic Editor: Peter J. Coombes \\ Received: 10 February 2017; Accepted: 28 March 2017; Published: 1 April 2017
}

\begin{abstract}
Construction in urban areas usually results in compacted soil, which restricts plant growth and infiltration. Nutrients may be lost in storm runoff water and sediment. The purpose of this study was to determine if existing lawns benefit from aeration and surface compost additions without the negative impact of nutrient loss in runoff. Four sets of lawns were compared, with or without compost plus aeration, as a paired comparison. Surface bulk density was significantly reduced in the treated lawns $\left(1.32\right.$ versus $\left.1.42 \mathrm{Mg} \cdot \mathrm{m}^{-3}\right)$. Visual evaluation of soil structure showed improvement in the treated lawns. Of fifteen measurement dates over four years, four dates showed significantly higher surface soil water contents in the treated lawns compared with the untreated lawns. When compared over time, three of the four treated lawns had significantly higher soil water content than the untreated lawns. Nutrient concentrations in rainfall simulator runoff were not significantly different between treated and control lawns, which showed that compost did not negatively impact water quality. Compost and aeration helped restore soil quality for urban soils of recent construction.
\end{abstract}

Keywords: soil quality; water quality; urban soil; rainfall simulator

\section{Introduction}

Construction in urban areas usually results in compacted soil which restricts plant growth and infiltration [1]. Reduced infiltration increases storm runoff and erosion [2] or ponding in low areas. Nutrients may be lost in storm runoff and sediment.

Aeration combined with surface compost additions may improve infiltration. Aeration (removal of small cores of soil) has primarily been used in golf course putting greens to reduce thatch build-up, decrease bulk density, and increase infiltration [3]. Loper et al. [4] and Evanylo et al. [1] observed that compost decreased bulk density and improved plant growth. Visual evaluation of soil structure (VESS) has been used to evaluate soil structure in agricultural soils [5], but not in urban soils.

Compost additions should be enough to aid plant growth, but not so much that excess nutrients are lost in runoff [6,7]. Persyn et al. [8] showed that surface compost blankets reduced sediment loss in runoff. Yard waste compost had higher soluble P in runoff than the control, but sorbed P loss in runoff was not significantly different [8]. Faucett et al. [9] observed significant reductions in runoff, sediment, and nitrate loss for surface compost additions. Franklin et al. [10] measured reduced runoff and total phosphorus loss with broiler litter, but aeration did not have a significant effect. Johnson et al. [11] did not observe any significant increases in total phosphorus or nitrate loss in runoff after compost additions up to $99 \mathrm{~m}^{3} \cdot \mathrm{Ha}^{-1}$ on bluegrass. Chaganti and Crohn [12] showed that green waste compost had significantly reduced runoff and sediment loss but significantly higher concentrations of ortho phosphate in the runoff. 
The purpose of this study was to determine if urban lawns benefit from aeration and surface compost additions without the negative impact of nutrient loss in runoff.

\section{Materials and Methods}

Four yards were selected, at different stages after construction. Two yards in Ankeny, Iowa, were around two years after construction, and two yards in Ames, Iowa, were more than five years after construction. Yard 1 at Ankeny and yard 1 at Ames had prior compost addition with aeration years before the study was started. Due to activity at the yard 1 Ankeny site, the compost used was from dairy manure with food wastes and sand, sieved with $12 \mathrm{~mm}$ chicken wire. For all other sites, a mixture of cow manure and yard waste clipping was used. This compost had $9.3 \mathrm{~g} \cdot \mathrm{kg}^{-1}$ of total nitrogen, and $384 \mathrm{mg} \cdot \mathrm{kg}^{-1}$ of ortho phosphate (Olsen [13]), but analysis of the dairy compost is not known. All compost was applied in the fall of 2012. First, the yards were aerated with $3.8 \mathrm{~cm}$ long tines on average $10 \mathrm{~cm}$ apart. Then, $1.3 \mathrm{~cm}$ depth of compost was applied at the surface and spread using a rake. The treated yards were paired with adjacent untreated yards.

Surface soil water content was monitored with a HydraProbe (Stevens Water Monitoring Systems, Inc., Portland, OR, USA) in both the improved yards as well as paired nearby yards without aeration and compost additions-six measurements in each yard. Some of the HydraProbe data gave spurious data (such as negative water content or log of a negative number during data processing), so mean soil water content per date/yard sometimes had measurements at fewer than six sites.

One year and three years after addition of compost and aeration, a small rainfall simulator [14] was used for the analysis of runoff, and loss of sediment and nutrients in the treated yards and nearby yards without treatment. The infiltrometer ring had an inner diameter of $241 \mathrm{~mm}$; rain was applied at $30 \mathrm{~cm} \cdot \mathrm{h}^{-1}$; slopes were small (1\%-2\%). Soil was dug out to allow for a runoff collection area. Runoff was continued for approximately sixty minutes after steady-state. Because the simulator was small, three to six replicates were measured on each treated yard and a nearby untreated lawn. For each yard, the runoff samples were combined by mixing for analysis of sediment and nutrients. Runoff samples were refrigerated until analysis. In the third year, the water used for infiltration was also analyzed for background nutrient levels. In year three, this extracted soil was examined to give the index from Visual Examination of Soil Structure (VESS: [5]). Observations [5] included aggregate firmness and porosity, roots interaction with aggregates, color, presence of earthworms, and soil texture by feel [15]. In the second year, disk infiltrometers [16], of $230 \mathrm{~mm}$ diameter, were used to determine infiltration rates at ponded, and $-30 \mathrm{~mm}$ head. There were five replicates in each treated yard and the paired yard.

Nitrate plus nitrite nitrogen was measured with a Lachet autoanalyzer using a Cd reduction $[17,18]$. Total phosphorus was determined using flow injection analysis [19] after acid-persulfate digestion. Runoff samples were dried at $105^{\circ} \mathrm{C}$ to determine sediment loss.

After three years, soil samples were collected to determine bulk density, total nitrogen, and organic and inorganic carbon. For each yard, six samples were collected with an incremental sampler [20] of $19 \mathrm{~mm}$ inner diameter. The samples were divided into 0-10, 10-20, and 20-30 $\mathrm{cm}$ and pooled by depth for each yard. Samples were taken after the first year for bulk density alone, and only to $20 \mathrm{~cm}$ depth. After obtaining moist mass, subsamples were oven-dried. Knowing the volume and oven-dried water content, bulk densities were determined. Air-dried samples were sieved $(2 \mathrm{~mm})$ before carbon and nitrogen analysis. Total carbon and nitrogen were determined by dry combustion [21] with a Fisons NA1500 Elemental Analyzer. Inorganic carbon [22] was determined by a pressure calcimeter, and organic carbon was determined by subtraction.

Each yard was paired with and compared to the nearby untreated yard. All properties were analyzed by paired comparisons [23] between treated and untreated yards across sites. Soil water differences between each lawn set were also compared over time, pairing by measurement date. Differences were considered significant at $\mathrm{p}=0.05$. 


\section{Results}

Four out of fifteen measurement dates showed significant increases in soil water content where the compost and aeration were applied (Table 1). Examining each yard pair over time showed that the two Ankeny sites $\left(0.281>0.243 \mathrm{~m}^{3} \cdot \mathrm{m}^{-3}, 0.292>0.225 \mathrm{~m}^{3} \cdot \mathrm{m}^{-3}\right)$ and one Ames site $\left(0.298>0.276 \mathrm{~m}^{3} \cdot \mathrm{m}^{-3}\right)$ had higher water content in the treated area than the untreated yards.

Table 1. Comparison ${ }^{1}$ of surface water $(0-6 \mathrm{~cm})$ for improved and control lawns.

\begin{tabular}{ccc}
\hline \multirow{2}{*}{ Date } & \multicolumn{2}{c}{ Soil Content Water $\left(\mathbf{m}^{3} \cdot \mathbf{m}^{-3}\right)$} \\
\cline { 2 - 3 } & Improved & Control \\
\hline $7 / 25 / 13$ & $0.247^{\mathrm{a}}$ & $0.216^{\mathrm{a}}$ \\
$8 / 14 / 13$ & $0.269^{\mathrm{a}}$ & $0.228^{\mathrm{a}}$ \\
$9 / 5 / 13$ & $0.183^{\mathrm{a}}$ & $0.193^{\mathrm{a}}$ \\
$9 / 25 / 13$ & $0.263^{\mathrm{a}}$ & $0.214^{\mathrm{b}}$ \\
$4 / 11 / 14$ & $0.323^{\mathrm{a}}$ & $0.282^{\mathrm{a}}$ \\
$5 / 5 / 14$ & $0.385^{\mathrm{a}}$ & $0.331^{\mathrm{a}}$ \\
$7 / 8 / 14$ & $0.326^{\mathrm{a}}$ & $0.263^{\mathrm{a}}$ \\
$7 / 30 / 14$ & $0.244^{\mathrm{a}}$ & $0.266^{\mathrm{a}}$ \\
$9 / 2 / 14$ & $0.332^{\mathrm{a}}$ & $0.250^{\mathrm{a}}$ \\
$5 / 13 / 15$ & $0.290^{\mathrm{a}}$ & $0.204^{\mathrm{b}}$ \\
$5 / 27 / 15$ & $0.380^{\mathrm{a}}$ & $0.339^{\mathrm{b}}$ \\
$8 / 7 / 15$ & $0.265^{\mathrm{a}}$ & $0.239^{\mathrm{a}}$ \\
$4 / 25 / 16$ & $0.293^{\mathrm{a}}$ & $0.258^{\mathrm{b}}$ \\
$5 / 16 / 16$ & $0.395^{\mathrm{a}}$ & $0.276^{\mathrm{a}}$ \\
$6 / 27 / 16$ & $0.265^{\mathrm{a}}$ & $0.252^{\mathrm{a}}$ \\
$8 / 25 / 16$ & $0.316^{\mathrm{a}}$ & $0.268^{\mathrm{a}}$ \\
\hline
\end{tabular}

${ }^{1}$ Within row treatments with the same superscripts (both ${ }^{a}$ ) are not significantly different at $p=0.05$, with the different superscripts $\left({ }^{\mathrm{a}}\right.$ and $\left.{ }^{\mathrm{b}}\right)$ are significantly different.

Bulk densities in the third year were significantly reduced in the $0-10 \mathrm{~cm}$ depth in the yards treated with compost and aeration $\left(1.32 \mathrm{Mg} \cdot \mathrm{m}^{-3}\right)$ compared with untreated areas $\left(1.42 \mathrm{Mg} \cdot \mathrm{m}^{-3}\right)$. There were no significant treatment effects on bulk density for the 10-20 cm or 20-30 cm depths $\left(1.60\right.$ and $\left.1.64 \mathrm{Mg} \cdot \mathrm{m}^{-3}\right)$ or for samples taken in the first year $\left(1.17\right.$ and $1.56 \mathrm{Mg} \cdot \mathrm{m}^{-3}$ for $0-10$ and 10-20 cm). Others have shown that compost reduces bulk density in urban soils $[1,4,24,25]$.

In the third year, organic $(1.23 \mathrm{~g} / 100 \mathrm{~g})$ and inorganic carbon $(0.62 \mathrm{~g} / 100 \mathrm{~g})$ as well as total nitrogen $(0.10 \mathrm{~g} / 100 \mathrm{~g})$ levels were not significantly affected by the treatments. Compost added to urban areas often increases soil organic carbon [1], at least in the long term [26]. At least eight years would be needed to detect significant management effects on soil carbon [27]. For unmanaged (unfertilized) areas, C-3 grasses decreased total nitrogen and C in soil [28], although C-4 grasses can increase C [29,30]. Spatial variation may require terrain co-variates to detect significant changes in soil C [31].

In the third year, VESS [5] showed significant improvement in the topsoil for compost plus aeration (1.2) compared with the control (2.3). Smaller VESS indicates better soil structure. Anything smaller than 3 is considered adequate soil structure [5], so even the control surface soil was okay. Earthworms were apparent in the surface soils at all sites, but not the subsurface. Most of the subsoils at Ankeny were gleyed, showing poor drainage and poor subsoil structure. Soil texture by feel indicated that most soils were loam or clay loam, but one site in Ames was sandy loam.

In the first year after establishing the treatments, the compost plus aeration yards did not show any significant effect on the infiltration rate $\left(41 \mathrm{~mm} \cdot \mathrm{h}^{-1}\right)$, runoff rate $\left(211 \mathrm{~mm} \cdot \mathrm{h}^{-1}\right)$, time to runoff, sediment loss $\left(0.25 \mathrm{~g} \cdot \mathrm{L}^{-1}\right)$, or $\mathrm{P}\left(0.30 \mathrm{mg} \cdot \mathrm{L}^{-1}\right)$ or nitrate concentrations $\left(1.17 \mathrm{mg} \cdot \mathrm{L}^{-1}\right)$ in runoff compared with untreated areas. Ponded $\left(20 \mathrm{~mm} \cdot \mathrm{h}^{-1}\right)$ and tension infiltration $\left(1.7 \mathrm{~mm} \cdot \mathrm{h}^{-1}\right)$ were not significantly affected by the compost and aeration in the second year. In the third year, again, there were no significant treatment differences in the infiltration rate $\left(184 \mathrm{~mm} \cdot \mathrm{h}^{-1}\right)$, runoff $\left(50 \mathrm{~mm} \cdot \mathrm{h}^{-1}\right)$, time to runoff, sediment loss $\left(0.26 \mathrm{~g} \cdot \mathrm{L}^{-1}\right)$ or loss of total phosphorus $\left(0.16 \mathrm{mg} \cdot \mathrm{L}^{-1}\right)$ or nitrate $\left(0.1 \mathrm{mg} \cdot \mathrm{L}^{-1}\right)$. 
Higher nutrient levels in the first year resulted from no blank being analyzed (background nutrient levels in the infiltration water).

Total phosphorus concentrations in runoff were at the low end for loss from grassed areas: 0.3 to $7.1 \mathrm{mg} \cdot \mathrm{L}^{-1}$ [30,32]. Sediment concentrations were low and similar to those shown by Logsdon et al. [29]. The addition of compost did not increase P loss compared with the control, which was also shown by Johnson et al. [11].

There were interesting trends in the rainfall simulator study, even though overall results were not significant between treated and control yards. One of the treated sites in Ankeny had longer time to runoff than all the other sites ( $4.5 \mathrm{vs.} 1.7 \mathrm{~min}$ in the first year; $5.8 \mathrm{vs} .1 .9 \mathrm{~min}$ in the third year). That site also had no sediment loss in the third year, whereas all other sites had some sediment loss. Time to runoff was generally lower than most values ( 2 to $78 \mathrm{~min}$ ) in the literature [30,32,33].

\section{Conclusions}

In the third year, surface bulk density and VESS were improved for compost plus aeration over the control. For over one-quarter of the measurement dates, the improved lawns had significantly higher soil water content, but the other measurement dates did not show significant differences in surface soil water content. Subsurface soil still showed the construction-imposed-compaction, especially for the sites in Ankeny, where restricted infiltration resulted in aeration problems. Runoff and sediment rates were not significantly affected by the treatments, but the sediment and nutrient losses were low for all yards. The compost treatments did not negatively affect the nutrient quality of runoff water.

Spatial variability of infiltration $[11,34,35]$, and slow recovery of organic carbon showed that these were non-sensitive tests for soil quality on urban soils. Bulk density and VESS were more useful tests, and would be recommended to detect improved physical soil quality, especially in the short term.

Supplementary Materials: The following are available online at http://www.mdpi.com/2073-4441/9/4/247/s1, Table S1: Monthly rain totals during the growing seasons. This is the mean of two rain gauges located south of Ames and north of Ankeny; Table S2: Infiltration and runoff rates (means) and water quality for 2014; Table S3: Hydraulic conductivity (means) for saturation (Ksat) and $-30 \mathrm{~mm}$ head in 2015, using disk infiltrometer; Table S4: Infiltration and runoff rates (means) and water quality for 2016.

Acknowledgments: Thanks to landowners who permitted measurements in their lawns. Thanks to Gavin Simmons for collecting the data. Thanks to Jolee Belzung for locating some of the landowners.

Author Contributions: Sally Logsdon and Pat Sauer conceived the experiments, Sally Logsdon directed conducting the experiments. Pat Sauer found contacts who assisted in located landowners for the experiments. Sally Logsdon wrote the manuscript with input from Pat Sauer.

Conflicts of Interest: The authors declare no conflict of interest.

\section{References}

1. Evanylo, G.K.; Porta, S.N.; Li, J.; Shan, D.; Goatley, J.M.; Maguire, R. Compost practices for improving soil properties and turfgrass establishment and quality on a disturbed urban soil. Compost Sci. Util. 2016, 24, 136-145. [CrossRef]

2. Knox, E.G.; Bouchard, C.E.; Barrett, J.G. Erosion and sedimentation in urban areas. In Managing Soils in an Urban Environment; Agronomy Monograph 39; Brown, R.B., Huddleston, J.H., Anderson, J.L., Eds.; ASA-CSSA-SSSA: Madison, WI, USA, 2000; pp. 179-197.

3. Atkinson, J.L.; McCarty, L.B.; Bridges, W.C. Effect of core aerification frequency, area impacted, and topdressing rate on turf quality and soil physical properties. Agron. J. 2012, 104, 1710-1715. [CrossRef]

4. Loper, S.; Shober, A.L.; Wiese, C.; Denny, G.C.; Stanley, G.D.; Gilman, E.F. Organic soil amendment and tillage affect soil quality and plant performance in simulated residential landscapes. HortScience 2010, 45, $1522-1528$.

5. Guimaraes, R.M.L.; Ball, B.C.; Tormena, C.A. Improvements in the visual evaluation of soil structure. Soil Use Manag. 2011, 27, 395-403. [CrossRef] 
6. Persyn, R.A.; Glanville, T.D.; Richard, T.L.; Laflen, J.M.; Dixon, P.M. Environmental effects of applying composted organics to new highway embankments: Part II. Water quality. Trans. ASAE 2004, 47, 471-478. [CrossRef]

7. Saebo, A.; Ferrini, F. The use of compost in urban green areas-A review of practical application. Urban For. Urban Green. 2006, 4, 159-169. [CrossRef]

8. Persyn, R.A.; Glanville, T.D.; Richard, T.L.; Laflen, J.M.; Dixon, P.M. Environmental effects of applying composted organics to new highway embankments: Part 1. Interrill runoff and erosion. Trans. ASAE 2004, 47, 463-469. [CrossRef]

9. Faucette, L.B.; Jordan, C.F.; Risse, L.M.; Cabrera, M.; Coleman, D.C.; West, L.T. Evaluation of stormwater from compost and conventional erosion control practices in construction activities. J. Soil Water Conserv. 2005, 60, 288-297.

10. Franklin, D.H.; Cabrera, M.L.; Calvert, V.H. Fertilizer source and soil aeration effects on runoff volume and soil quality. Soil Sci. Soc. Am. J. 2006, 70, 84-89. [CrossRef]

11. Johnson, G.A.; Davis, J.G.; Qian, Y.L.; Doesken, K.C. Topdressing turf with composted manure improves soil quality and protects water quality. Soil Sci. Soc. Am. J. 2006, 70, 2114-2121. [CrossRef]

12. Chaganti, V.N.; Crohn, D.M. Evaluation of compost blankets for erosion control and runoff water quality on a constructed hillslope in southern California. Trans. ASABE 2014, 57, 403-416. [CrossRef]

13. Olsen, S.R.; Cole, R.V.; Watanabe, F.S.; Dean, L.A. Estimation of Available Phosphorus in Soils by Extraction with Sodium Bicarbonate; Circular No. 939; U.S. Department of Agriculture: Washington, DC, USA, 1954; pp. 1-19.

14. Ogden, C.B.; Van Es, H.M.; Schindelbeck, R.R. Miniature rain simulator for field measurement of soil infiltration. Soil Sci. Soc. Am. J. 1997, 61, 1041-1043. [CrossRef]

15. Thien, S.J. A flow diagram for teaching texture by feel analysis. J. Agron. Educ. 1979, 8, 54-55.

16. Perroux, K.M.; White, I. Designs for disc permeameters. Soil Sci. Soc. Am. J. 1988, 52, 1205-1215. [CrossRef]

17. Wood, E.D.; Armstrong, F.A.J.; Richards, F.A. Determination of nitrate in seawater by cadmium-copper reduction to nitrite. J. Mar. Biol. 1967, 47, 23-31. [CrossRef]

18. Tomer, M.D.; Moorman, T.B.; Rossi, C.G. Assessment of the Iowa River's South Fork watershed: Part 1. Water quality. J. Soil Water Conserv. 2008, 63, 360-370. [CrossRef]

19. Determination of Phosphorus by Semi-Automated Colorimetry; Method 365.1, Revision 2.0; United States Environmental Protection Agency: Cincinnati, OH, USA, 1993. Available online: https:/ /www.epa.gov / sites/production/files/2015-08/documents/method_365-1_1993.pdf (accessed on 9 March 2017).

20. Pikul, J.L.; Allmaras, R.R. Physical and chemical properties of a Haploxeroll after fifty years of residue management. Soil Sci. Soc. Am. J. 1986, 50, 214-219. [CrossRef]

21. Nelson, D.W.; Sommers, L.E. Total carbon, organic carbon, and organic matter. In Methods of Soil Analysis. Part 2. Chemical and Microbiological Properties, 2nd ed.; Page, A.L., Miller, R.H., Keeney, D.R., Eds.; ASA, SSSA: Madison, WI, USA, 1982; pp. 539-579.

22. Sherrod, L.A.; Dunn, G.; Peterson, G.A.; Kolberg, R.I. Inorganic carbon analysis by modified pressure calcimeter method. Soil Sci. Soc. Am. J. 2002, 66, 299-305. [CrossRef]

23. Karlen, D.L.; Sadler, E.J.; Busscher, W.J. Crop yield variation associated with Coastal plain soil map units. Soil Sci. Soc. Am. J. 1990, 54, 859-865. [CrossRef]

24. Cogger, C.G. Potential compost benefits for restoration of soils disturbed by urban development. Compost Sci. Util. 2005, 13, 243-251. [CrossRef]

25. Singer, J.W.; Malone, R.W.; Tomer, M.D.; Meade, T.G.; Welch, J. Compost effect on water retention and native plant establishment on a construction embankment. J. Soil Water Conserv. 2006, 61, 268-273.

26. Huyler, A.; Chappelka, A.H.; Prior, S.A.; Somers, G.L. Drivers of soil carbon in residential 'pure lawns' in Auburn, Alabama. Urban Ecosyst. 2014, 17, 205-219. [CrossRef]

27. Necpalova, M.; Anex, R.P., Jr.; Kravchenko, A.N.; Abendroth, L.J.; Del Grosso, S.J.; Dick, W.A.; Helmers, M.J.; Herzmann, D.; Lauer, J.G.; Nafziger, E.D.; et al. What does it take to detect a change in soil carbon stock? A regional comparison of minimum detectable difference and experiment duration in the north central United State. J. Soil Water Conserv. 2014, 60, 517-531. [CrossRef]

28. Knops, J.M.H.; Tilman, D. Dynamic of soil nitrogen and carbon accumulation for 60 years after agricultural abandonment. Ecology 2000, 81, 88-98. [CrossRef] 
29. Yost, J.L.; Egerton-Warburton, L.M.; Schreiner, K.M.; Palmer, C.E.; Hartemink, A.E. Impact of restoration and management on aggregation and organic carbon accumulation in urban grasslands. Soil Sci. Soc. Am. J. 2016, 80, 992-1002. [CrossRef]

30. Logsdon, S.D.; Sauer, P.; Shipitalo, M.J. Compost improved urban soil and water quality. J. Water Resour. Prot. 2017, Accepted.

31. Kaspar, T.C.; Parkin, T.B.; Jaynes, D.B.; Cambardella, C.A.; Meek, D.W.; Jung, Y.S. Examining changes in soil organic carbon with oat and rye cover crops using terrain covariates. Soil Sci. Soc. Am. J. 2006, 70, 1168-1177. [CrossRef]

32. Ramírez-Ávila, J.J.; Stomayor-Ramírez, D.; Martinex-Rodríguez, G.A.; Pérez-Alegría, L.R. Phosphorus in runoff from two highly weathered soils of the tropics. Can. J. Soil Sci. 2011, 91, 267-277. [CrossRef]

33. Krenitsky, E.C.; Carroll, M.J.; Hill, R.L.; Krouse, J.M. Runoff and sediment losses from natural and man-made erosion control materials. Crop Sci. 1997, 38, 1042-1046. [CrossRef]

34. Logsdon, S.D.; Jordahl, J.L.; Karlen, D.L. Tillage and crop effects on ponded and tension infiltration rates. Soil Tillage Res. 1993, 28, 179-189. [CrossRef]

35. Logsdon, S.D.; Kaspar, T.C. Tillage influences as measured by ponded and tension infiltration. J. Soil Water Conserv. 1995, 50, 571-575.

(C) 2017 by the authors. Licensee MDPI, Basel, Switzerland. This article is an open access article distributed under the terms and conditions of the Creative Commons Attribution (CC BY) license (http:/ / creativecommons.org/licenses/by/4.0/). 